\title{
Platinum Group Element Constraints On The Origin Of Cratonic Peridotites : A Study Of Kimberley Peridotite Xenoliths
}

\author{
Irvine, G.J. ${ }^{1}$, Pearson, D.G. ${ }^{1}$, Carlson, R.W. ${ }^{2}$ and Boyd, F.R. ${ }^{3}$ \\ ${ }^{1}$ Department of Geological Sciences, University of Durham, South Rd., Durham, DH1 3LE, UK \\ 2 Carnegie Institute, Department of Terrestrial Magnetism, 5241 Broad Branch Rd. NW, Washington, \\ D.C. 20015 , USA \\ ${ }^{3}$ Carnegie Institute, Geophysical Laboratory, 5251 Broad Branch Rd. NW, Washington, D.C. 20015, USA
}

\section{Introduction}

The nature of tectonic and mantle differentiation processes operating in the Archaean Earth remain an important goal in understanding Earth evolution. Significant insight into this problem may be gained by direct study of mantle xenoliths. Isotope studies of xenoliths have shown that at least two major cratons were underlain by mantle keels more than $150 \mathrm{~km}$ thick by the mid-Archaean.

Although highly depleted in basaltic components, the major element composition of cratonic peridotites, specifically their large and varied enstatite contents, preclude them being simple residues from mantle melting. This over-abundance in enstatite, manifest as a Si-enrichment is enigmatic and a number of different origins have been proposed to account for it. (1) $\mathrm{Fe} / \mathrm{SiO}_{2}$ trends in xenoliths from Udachnaya can be interpreted as reflecting mixing-unmixing processes such as metamorphic differentiation, cumulate sorting and mixing of cumulates and residues (Boyd, 1997, Walter, 1997), (2) Melting in Archaean super-plumes (Herzberg, 1993, Herzberg, 1997), (3) Mantle-melt interaction forming enstatite (Rudnick et al, 1994, Kelemen et al, 1992). Positive correlations between $\mathrm{Ni}$ content of olivine and modal orthopyroxene may be indicative of $\mathrm{SiO}_{2}$ addition to a high $\mathrm{Mg \#}$ protolith (Kelemen, 1997). It has therefore been suggested that silica may have been produced from small degree melts of subducted eclogites and that subduction and collision related stacking created thick cratonic roots (Kelemen, 1997). Rudnick (1997) has suggested that cratonic eclogite xenoliths represent residues of slab melting. The eclogites may therefore have been a source of silicic magmas capable of causing Si-enrichment of lithospheric peridotites. T-T-G suites, which are very important in Archaean crust, have REE compositions, $\mathrm{Mg \#}$ and $\mathrm{Ni}$ contents suggesting they were formed from the silicic magmas after interaction with the lithospheric mantle, as represented by the xenoliths. These alternatives are testable by geochemical analysis and we have chosen to apply Platinum Group Elements (PGE's) to investigate the problem.

\section{Platinum Group Elements}

A suite of spinel- and garnet-facies peridotite xenoliths from the Kimberley area, displaying modal abundance variation and systematic major element differences between the two facies, were analysed for Re-Os isotopes. PGE abundances were analysed by ICP-MS using isotope dilution on an ELAN 6000. Analyses were made using both cross-flow and direct injection nebulisers (DIN). The detection limits for the DIN were 3ppt for Re, Os and Ir, 20ppt for Pt and Pd. Samples were digested in Carius tubes. Os was solvent extracted and other PGE's separated by anion-exchange chromatography. Re, Os, Pt, Pd, Ir and Ru are all taken off the same sample dissolution eliminating the effects of powder heterogeneity. PGE's are compatible to moderately incompatible elements and their systematic behaviour can be used to trace magmatic processes in mantle samples. Due to their relatively high abundances in mantle rocks PGE's are also relatively unaffected by metasomatism compared to incompatible elements. PGE's can therefore be utilised to show differences between melting and fractional crystallisation products. These characteristics make 
PGE's very useful for constraining the origins of cratonic peridotites with reduced interference from subsequent processes.

\section{Initial results}
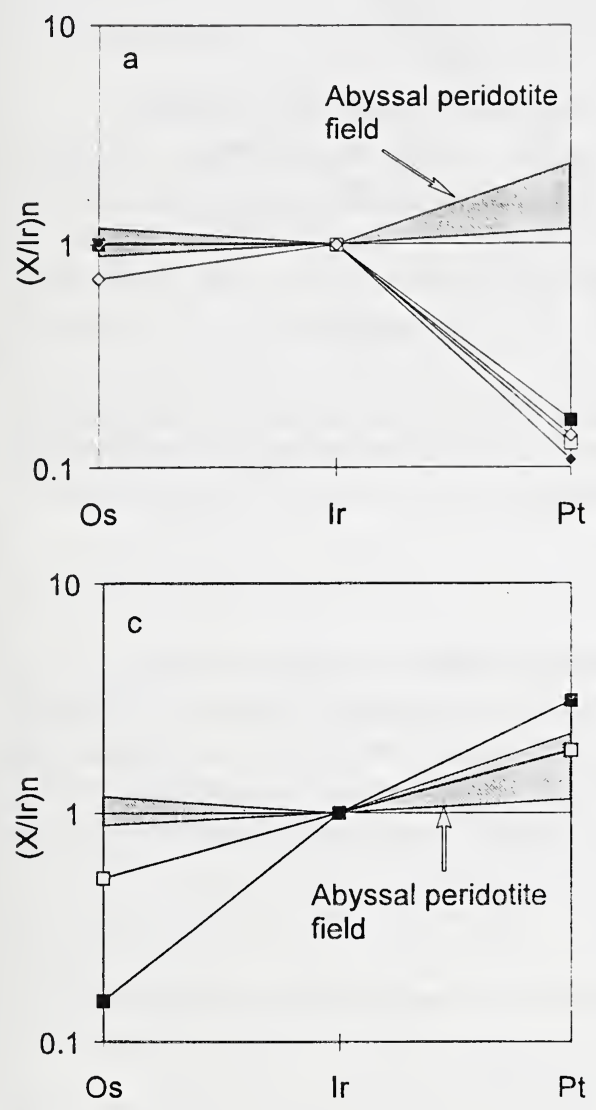

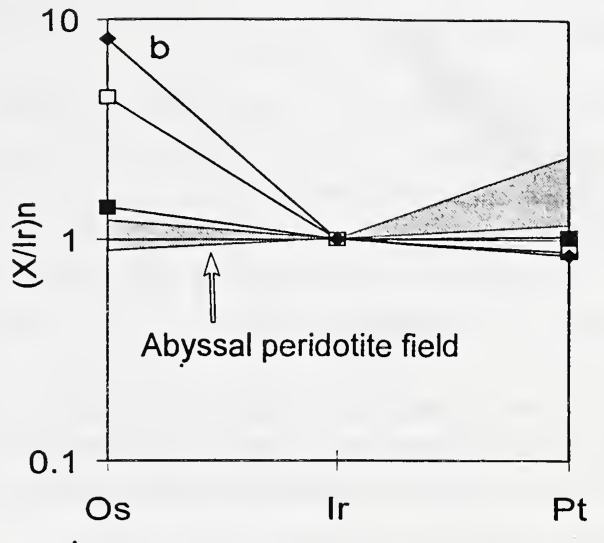

Figure 1 Os-Ir-Pt abundances for Kimberley xenoliths normalised to Ir and C-chondrites. Shown for comparison and represented by the shaded area is the field for Abyssal peridotite data (Snow and Schmidt, 1998).

Figure 1 shows that cratonic xenolith PGE abundances and inter-element fractionation not only vary greatly from abyssal peridotites but that there is also a great variance between individual cratonic peridotites. From the initial dataset there appears to be 3 distinct trends observed. The group shown in Fig. la have near chondritic Os/Ir but a depletion in Pt. These samples may represent residues where Os and Ir are retained in refractory phases while Pt is released into the melt. Figure Ic shows a trend similar to that of a melt, with the high temperature PGE's being depleted and low temperature PGE's $(\mathrm{Pt})$ becoming relatively more enriched. By comparison, figure $1 \mathrm{~b}$ shows a trend more similar to certain cumulates with the high temperature PGE's becoming enriched and low temperature PGE's being relatively depleted. To what extent these results actually represent any of these specific processes is still uncertain and work is ongoing. More over, the effect of meltrock reaction on PGE abundances is currently poorly constrained. Clearly different processes are involved in generating the PGE signature of the rocks. Some of the cratonic xenoliths studied here have close to chondritic inter-element ratios (Fig. 2 and 3), falling within the same field as oceanic xenoliths (Fig. 2). However several cratonic samples have very fractionated PGE ratios. The large degree of PGE fractionation within a single cratonic peridotite suite clearly illustrates the potential of the elements for understanding the genesis of cratonic mantle. 


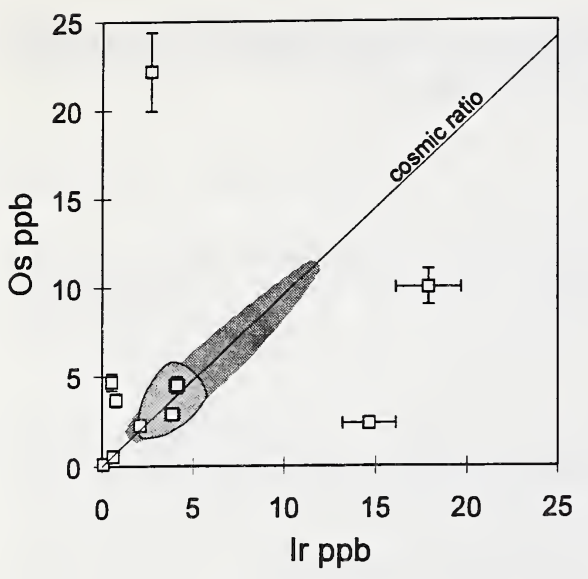

Figure 2 Os-Ir correlation with comparisons to spinel Iherzolites from basalts (light grey shading) and Gnt Iherzolites from Lesotho (dark grey shading) (Morgan et al, 1981)

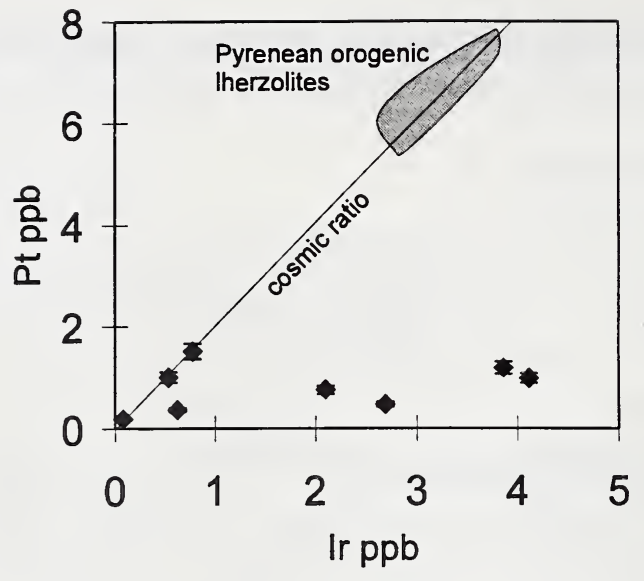

Figure 3 Pt-Ir correlation with comparison to Pyrenean orogenic Iherzolites (Pattou et al, 1996)

\section{Summary}

Platinum group elements show that cratonic peridotite samples have a complex history possibly indicative of varied magmatic processes. A large proportion of the samples analysed so far differ greatly from modern melt residues. PGE's do however provide the opportunity to gain insights into the processes involved in the origin of sub-cratonic mantle lithosphere relatively unaffected by host rock metasomatism. Early results are already showing systematic trends, but the dataset is small and work is ongoing

\section{References}

Boyd, F.R., 1997, Correlation of orthopyroxene Abundance with the Ni content of coexisting olivine in cratonic peridotites: EOS, Trans. Am. Geophys. Soc., vol.78, F746.

Herzberg, C.T., 1993, Lithosphere peridotites of the Kaapvaal craton: Earth Planet. Sci. Lett., 120, p.13-29.

Herzberg, C.T., 1997, Formation of cratonic mantle as residues and cumulates: EOS, Trans. Am. Geophys. Soc., vol.78, F746-F747.

Kelemen, P.B, Dick, H.J.B. and Quick, J.E., 1992, Formation of harzburgite by pervasive melt/rock reaction in the upper mantle: Nature, vol 352, p.635-641.

Kelemen, P.B., 1997, $\mathrm{SiO}_{2}$ addition to cratonic mantle via melt/rock reaction above subduction zones: EOS, Trans. Am. Geophys. Soc., vol.78, F747.

Morgan, J.W., Wandless, G.A., Petrie, R.K. and Irving, A.J., 1981, Composition of the Earth's upper mantle - I. siderophile trace elements in ultramafic nodules: Tectonophysics, 75, p.47-67.

Pattou, L., Lorand, J.P. and Gros, M., 1996, Non-chondritic platinum group element ratios in the Earth's mantle: Nature, vol 379, p. 712-715.

Rudnick, R.L., M Donough, W.F. and Orpin, A., 1994, Northern Tanzanian peridotite xenoliths: A comparison with Kaapvaal peridotites and inferences on metasomatic interactions, in: Proc. of the $5^{\text {th }}$ Int. Kimberlite Conf., Meyer, H.O.A. and Leonardos, O., eds., p.336-353.

Rudnick, R.L., 1997, Speculation on crust-mantle connections in the Archaean: EOS, Trans. Am. Geophys. Soc., vol.78, F747.

Snow, J.E. and Schmidt, G., 1998, Constraints on Earth accretion deduced from noble metals in the oceanic mantle: Nature, vol 391, p.166-169.

Walter, M.J., 1997, Origin of cratonic peridotite: A test for sorting of olivine and orthopyroxene: EOS, Trans. Am. Geophys. Soc., vol.78, F747. 